\title{
SITUATION ANALYSIS OF TOURISM-RELATED BUSINESSES IN A REFERENTIAL RESORT AREA OF HUNGARY
}

Erzsébet Péter, Dr., Assistant professor

Faculty of Economics of the University of Pannonia

Address: $\quad$ Nagykanizsa Campus, 8800-Nagykanizsa, Zrínyi M. u. 33.

E-mail: $\quad$ peter.erzsebet@uni-pen.hu

Zoltán Birkner, Director of the campus

Faculty of Economics of the University of Pannonia

Address: $\quad$ Nagykanizsa Campus, 8800-Nagykanizsa, Zrínyi M. u. 33.

E-mail: $\quad$ birkner.zoltan@uni-pen.hu

Beáta Fehérvölgyi, Assistant lecturer

Faculty of Economics of the University of Pannonia

Address: $\quad$ Nagykanizsa Campus, 8800-Nagykanizsa, Zrínyi M. u. 33.

E-mail: $\quad$ fehervolgyi.beata@uni-pen.hu 


\section{SITUATION ANALYSIS OF TOURISM-RELATED BUSINESSES IN A REFERENTIAL RESORT AREA OF HUNGARY}

Key words: Hungary, Preferential Holiday Resort Area of Lake Balaton, the situation of the retail trade, catering, holiday-makers' habits, businesses

The aim of the research is to reveal the characteristics of one of Hungary's most important touristic destination, the Lake Balaton Resort Area, with special respect to what sort of influence on local businesses foreign-owned commercial supermarket chains have. The research involves mapping transformed businesses, as well as searching for the answer to how the tendency of the periods of high season and the changing of the visitors' segments affect catering industry. In addition to this, the study draws a comparison between the motivation of setting up businesses and the year of their launch.

In the Lake Balaton Resort Area, which serves as the locality of the particular research, it can be observed that the importance of the service industry is on the increase, which ensures the possibility of an alternative source of income to the local inhabitants. In the first place, it directly affects the labour force, driven out of the primary sector jobs, who are on the verge of having the service industry as the only chance to get a job. The study is aimed at commercial concentration and the changing of the catering industry, besides the breakdown of the region's businesses into separate branches. The main question of the examination is whether the economic priority of tourism may be sufficient enough in the future to kick-start the development of this specific rural region, or further diversification of branches should be required in the interest of development. While mapping the characteristics of the layers of micro, small and medium-sized enterprises, we have been looking for the answer to how economic-sociological processes that are present in the Lake Balaton Resort Area influence their successfulness.

The development of tourist destinations, the improvement of living standards and the enhancement of the Balaton identity can be supported by the self-employment and creating jobs. To achieve that, it is inevitable for the local inhabitants to pool their interests and co-operate. 


\section{MATERIAL AND METHODS}

From a functional point of view, the location of the empirical research might be even a separate region, however, it comprises settlements in three different regions and three different counties at the moment. The settlements in the counties Somogy, Zala and Veszprém make up the Lake Balaton Resort Area (LBRA). The resort area consisting of 164 towns and villages is home to almost 26.000 enterprises, while the number of catering establishments run in the area may as well increase by $10 \%$ in high summer season. Divided into statistical small regions in the Lake Balaton Resort Area, those 164 settlements constituted the location of the research, based on the Act 2000 CXII, the Lake Balaton Resort Area Site Development Regulation. A representative survey has been carried out with about 300 questionnaires used and processed. Compared with the whole multitude, the rate of questioning was $2,64 \%$ in the case of enterprises doing business in retail trade, while it was 3,07\% among the businesses being run in the field of catering. Asking people the questions, compiled in the questionnaires, lasted from May 2005 to March 2006. While choosing the samples, we took into consideration the number of businesses, as well as their distribution and breakdown by methodological small regions. Creating methodological small regions was necessary, because the boundaries of the statistical small regions and those of the Lake Balaton Resort Area do not cover each other. Representivity was ensured by us classifying the businesses as to whether they can be found near the shore of the lake or in settlements further away, and by drawing a distinction between businesses run in towns and villages (communities) according to their size, sectors and also sub-sectors. In the case of micro, small and medium-sized enterprises, we chose the Equal Probability Selection Method (Babbie, 2001) to get the proper samples. 375 enterprises were asked, out of which 300 were able to be evaluated, as there were questionnaires filled in insufficiently and asking the questions was made difficult by the repliers' fear of possible subsequent controls of the authorities. $79 \%$ of those questioned were micro-sized enterprises, $15 \%$ small ones, and $6 \%$ medium-sized businesses, who were asked during the poll. In the qualitative examination seven interviews were made, which were aimed at their determining presence in the region and their future prospects of business, in addition to the economic and social changes affecting tourism by Lake Balaton. The set up hypotheses were examined by means of correlation analysis, regression analysis and cross table analysis. 


\section{CHANGES IN THE NUMBER OF TOURISTS IN HUNGARY'S RESORT AREAS}

Looking at the regional distribution of tourism in Hugnary, most tourist nights were registered in Central Hungary, as well as in Western and Southern Transdanubia. On the other hand, still an insignificant part of guest nights spent in the country is registered in the regions to the east of the Danube. The regional concentration of foreign tourist nights is even bigger: every second night spent by foreign tourists is registered in Central Hungary, but only every ten tourist nights are spent in the three statistical regions lying east of the Danube at the same time.

With the number of tourist nights evaluated at the level of small regions, it remains to be only the preferential resort areas (especially Lake Balaton, Sopron-Köszeg-Hegyalja, and Mátra-Bükk), in the area of thermal spas (mainly Harkány, Zalakaros, Hajdúszoboszló, Gyula -Figure1) and major cities (Győr, Pécs, Szeged and Debrecen) in the country where most of the tourist nights have been registered besides Budapest. The number of tourist nights continues to be too low in the eastern regions and in the southernmost borderland regions of the country.

The average length of stay is not more than three days, as opposed to the European average length of stay of 4-5 days. While the utilization of many tourist attractions is still low, tourism is characterised by high seasonality and regional concentration. The nights spent by foreign tourists in Budapest and the Lake Balaton Resort Area account for $61 \%$, and - in terms of time - their 37\% falls on the months of July and August (KSH - Hungarian Central Statistical Office; Mester et al, 2006). 
Figure 1: the territorial coverage of the preferential Resort Areas in Hungary

Budapest The near-shore towns and settlements in the Lake Balaton Resort Area 口 Other towns and settlements in the Lake Balaton Resort Area The Danube Bend Resort Area The Mátra-Bükk Resort Area

The Mecsek and Villány Resort Area The Lake Tisza Resort Area The Lake Velence-Vértes Resort Area

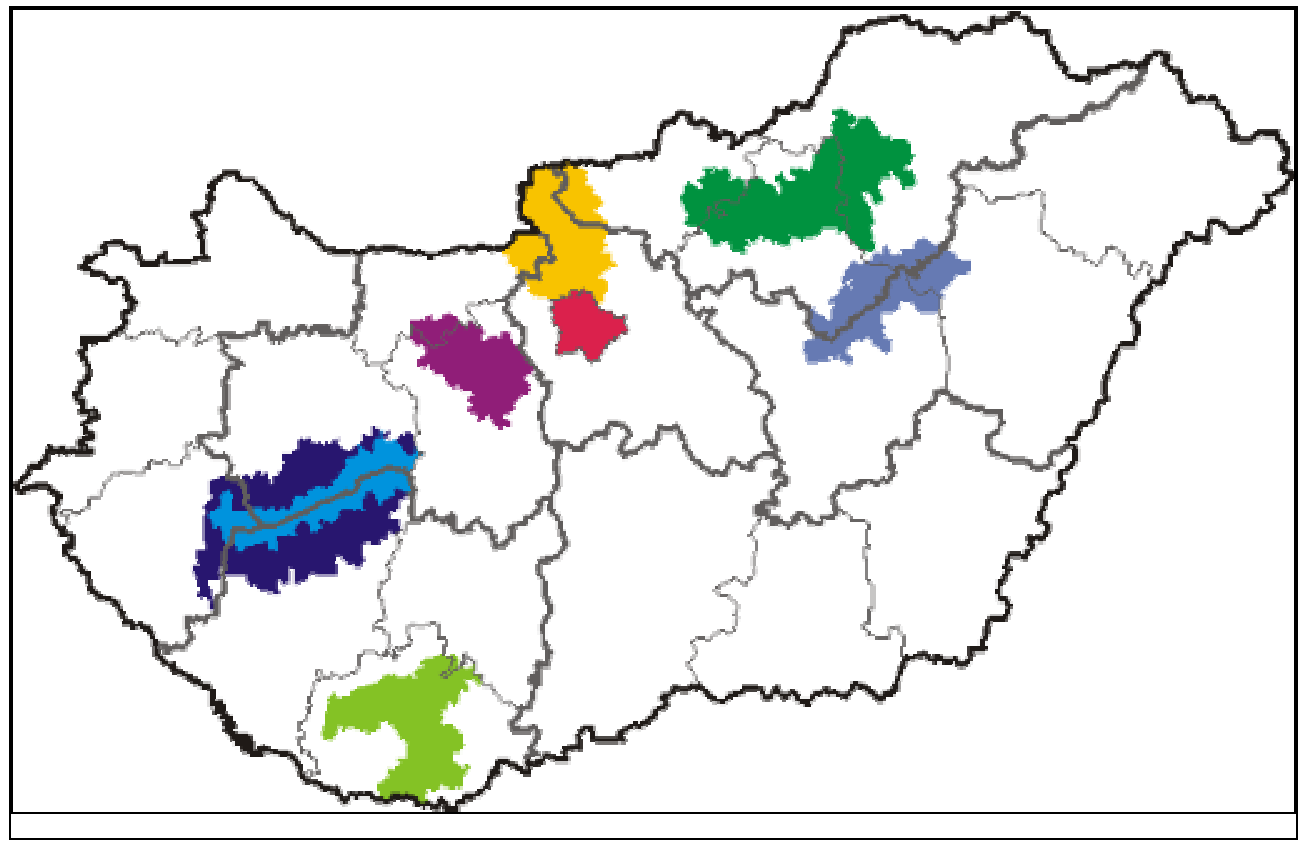

Source: Népszámlálás (Census), 2001

Considering the number of hotels, campsites, holiday homes and resorts, where tourists and holiday home owners can stay, their number is the biggest in the near-shore towns and villages in the Lake Balaton Resort Area: 65 thousand (which accounts for 25\% of the total number). ,, The Danube Bend accounts for 11 per cent (28 thousand), then comes the area of Lake Velence-Vértes and, then, that of Mecsek and Villány with 5 per cent each (with more than 12 thousand places of accommodation in each resort area). Then comes the Mátra-Bükk Resort Area ( 8 thousand, which is 3\%), followed by the area of the other towns and settlements further from the lake in the Lake Balaton Resort Area (5 thousand, 2\%), and finally comes Lake Tisza, of which surrounding area has only 2800 places of accommodation $(1,1 \%)$. The seventh preferential resort area is Budapest, however, it is not likely to be put down to the number of places of accommodation, rather than the touristic 
significance of the capital itself. The number of places of accommodation listed in Budapest is 3400 , which has a share of $1,4 \%$ of the total. , (Census, 2001).

Consequently, there are seven preferential Resort Areas in Hungary, with the LBRA's near-shore and other towns and settlements separated in some cases, as it can be seen in Figure1. The Lake Balaton Resort Area, the Lake Tisza Resort Area, the Lake Velence-Vértes Resort Area, and the Danube Bend are resort areas that have similar characteristic features and natural endowments. All the four can be connected to water. Nevertheless, they are very different on the bases of territorial coverage, the number of inhabitants and businesses.

Hungary's second most beautiful lake is Lake Tisza, with and area of $127 \mathrm{~km}^{2}$. According to the Parliamentary Act 35/1998. (III. 20), the Lake Tisza Resort Area consists of 23 towns and villages under the authority of four counties. This area was specified as an integrated development site of nationwide importance in the Parliamentary Act 77/2005. (XII. 25.) coming into force in 2005. The area does not possess an industrial potential; economic activities of light industry and food industry are the most common here, and tourism has also been improving in the smallest resort area in the country. The commercial and private accommodation facilities could accommodate up to 10.100 guests in the high season of 2006. This makes up only $4 \%$ of the room capacity in the Lake Balaton Resort Area, and the number of its visitor nights account for only $2 \%$ of the above mentioned (LBRA). During the year of the research there were 5088 catering facilities in the LBRA, while there was only a fragment of that number around Lake Tisza, 381 units of catering (KSH - Hungarian Central Statistical Office, 2008). All in all, no comparison can be drawn between the Lake Tisza Resort Area and the one I have been examining.

The number of the towns and villages in the Lake Velence-Vértes Resort Area is 33, where 2 towns and 31 villages/communities can be found. The number of its shops in retail trade hardly makes up 1/5 of that of the LBRA's similar enterprises. It became a preferential Resort Area in 1990 (Parliamentary Act 35/1998 (III.20.)) and its Development Council was set up in 2001. One fifth of the businesses being run here is connected to industry and construction industry, and the same proportion represents itself in retail trade, while $10 \%$ of them in accommodation services and catering. Demand for many-star hotels has arisen here, too, because of the changing touristic demands. Gárdony is taking the lead in meeting the needs of quality tourism (KSH - Hungarian Central Statistical Office, 2001).

The Danube Bend Resort Area includes 66 towns and villages and has gone through notable development in recent years. In 2000 the number of visitor nights reached 350.221, 
which is insignificant in comparison with the LBRA's 5 million visitor nights in the given year, however, it showed an increase of 5, 1\% compared to the previous year. Representing the area's interests at a municipal level is controlled by the Danube Bend Regional Site Development Council, which initiated increasing the number of settlements to 72 . What the Balaton area and the Danube Bend have in common is that both have remarkable tourist attractions, and both belong to 3 counties and 3 regions of development. It causes difficulties to both resort areas that they play a "mosaic-like", fragmentary role in the site development concepts of the regions in charge, and are pushed into the background when it comes to distributing public money (Turisztikai adattár - Toursitic reference book, 2008).

Out of the tourist destinations that can be found in our country, it is the Lake Balaton Resort Area that can consider $40 \%$ its own, that is the biggest number of tourists, the Germans, which is almost twice as many as the average ratio counted, based on the total number of foreign visitors. The Budapest-Central Danube Area attracts the second biggest number of German tourists, though, proportionately fewer people than in the case of average foreigners. (KSH - Hungarian Central Statistical Office, 2007).

In the '70s and ' $80 \mathrm{~s}$, Lake Balaton attracted foreign visitors, as it was easily accessible and taking a holiday there was relatively cheap. In comparison with the other socialist countries Hungary had a more liberal atmosphere, but it ensured a legal and safe meeting place for the citizens of the two German states separated by political borders. In 1980 the lake was visited by 825 thousand people, nearly half of which was foreign. In 1990 the area was visited by 725 thousand people, $77 \%$ of which were foreign citizens. Unfortunately the quality of the water deteriorated during this period of time (e.g.: fish perishing in large numbers), the number of trade union holidays dropped and solvent demand declined as a result of the population's uncertainty of existence after the change of regime. Unskilled and unqualified businessmen appeared in large numbers, and the profit interests of new entrepreneurs and small businessmen often took their toll on the quality of services (Buday-Sántha, 2007).

In the year of the empirical research there were altogether 1.461 .668 people visiting the area, $89 \%$ of which were registered in the area along the shore of the lake, while $11 \%$ of the people were registered in other towns and villages. The latter ones visited mainly the spas of Hévíz and Zalakaros that are situated near the south-western shore of Lake Balaton. About $33 \%$ of the visitors were foreign, mainly Austrian and German tourists. The growing number of people visiting the area is to be attributed to holidays abroad getting more 
expensive and the introduction of holiday vouchers, which resulted in the increasing number of domestic tourists at the same time.

\section{TRANSITIONAL ECONOMY}

In the 1990s basic changes were to be witnessed in Hungary's retail trade due to the process of privatisation. New businesses appeared because of the changing of the proprietors and that of customers' habits. The working capital flowing into Hungary from abroad resulted in significant changes in the country's economy within a decade. Due to its important multiplicating effects, the foreign operating capital presented new corporate management, new attitude to work and work ethic, service and financial background to the participants of the economy. Retail trade belongs to the field of the research where improvement can be measured in the most discernible way. Retail chains and shopping centres running in large sites possess up-to-date equipment and an appropriate assortment of goods by means of external investment of capital. New networks and adequate channels of distribution could be established through developments. At the same time domestic retail industry dwindled, and micro-sized businesses employing only a few people lost ground in the area.

Food retailers' answer to businesses with good financial standing entering the market was to cluster together into business chains ever more vigorously in Hungary, as well. This transition made it possible for small businesses to be a match for big companies with good financial standing at trading. In a similar way, catering was also transformed, which can be put down to the fact that the segments of tourists coming to Lake Balaton transformed, while holidaymakers' habits changed. The new target group required more modern accommodation and better services. The radical changes in tourism have resulted in improving the quality of catering facilities.

Several types of businesses can be distinguished also around Lake Balaton from the point of view of their orientation, too. "According to production-oriented companies, success lies in the quality of products or services, which are as good as possible, independent of the actual customers' demands. It is characteristic of sales-oriented companies that they put the emphasis on their own sales demands against fulfilling customers' demands. Their main problem derives from how to find more and more people who will buy their services, not from how to make them meet the demands of the widest possible range of customers. Marketing or customer-orientation means accepting and 
applying the marketing concept, that is, being aware of the fact that customers' needs and requirements are primarily essential." (Jancsik, 2001). As long as a company wants to do well and survive in the long run, it has to set its objectives of development according to this latter point of view.

Among the towns and villages in the Lake Balaton Resort Area, a certain kind of intraregional difference in development has appeared, one of which main reasons is the following: the concentration of the area's leading industry - tourism. As a result of this, the near-shore towns and villages ended up having essential advantages of development over the other places in the region. (Molnár 2001).

A given area's population-retaining power lies in ensuring jobs to local people who can make a living during the whole year either as self-employed or as acknowledged labour force. This is reason why it is important to know how entrepreneurs appreciate their employees, what opening hours the business has, whether it is seasonal or available for customers throughout the whole year.

According to prevailing laws, the Balaton Region does not have its own geographical region and obviously this is why it cannot even have its own source of financing, either. In the first place, it is not the autonomous economical and social framework programme of classical regional development that the LBRA requires. It is rather the base centres of economic rehabilitation, education-training and further training that it requires and are based on business-municipal-governmental elements and provide services for the Transdanubian Region according to the regions' needs.

For the time being, the Balaton Act consisting of changes valid from 1 December 2008 does not seem to attract investors as expected. According to the changes, an area of more than 5 thousand hectares in the resort area is qualified as a district to be built up and to be developed. Compared with the previous situation, it is a major change that, to get a building permit, it is not a basic condition for the settlements any more to have its $60 \%$ provided with wastewater pipes, but to have a wastewater plant on the spot. In the modification of the Balaton Act, basic priorities are represented by ecological requirements, landscaping, aspects of environmentalism, as well as regulations, taking into consideration the characteristic features of the landscape, towns and villages and the architecture of rural heritage.

\section{THE CHARACTERISTICS OF BUSINESSES IN THE EXAMINED REGION}


The entrepreneurs regarded sales and extending the market as the biggest problems. However, the majority had their own capital when setting up the business, many of them asked their relatives for help and took out bank loans. Nevertheless, this might have caused cash flow problems with the developments. Most money was spent on complying with EUregulations, improvement and renovation.

The entrepreneurs mostly employ one employee, while taking part in running the business themselves. $32 \%$ of the total is made up of micro-sized businesses employing 2 to 5 people. $94 \%$ of all the employees work as registered labour force. In terms of qualification the employees are mainly skilled workers, have a qualification of medium level and speak German at elementary level. A minor part of them can communicate in English and Russian, as well.

The period of summer high season (4 months) influenced $53 \%$ of the turnover of businesses around Lake Balaton. With its $24 \%$, it had a significant effect on the turnover in a positive way. We came to an interesting result, while calculating the correlation between seasonality and the number of employees. We received a negative medium correlation, of which explanation is that the bigger the enterprise in terms of the category of its staff's number, the less it is affected by seasonality and the more employees it ensures jobs during the whole year, as these businesses are based not only on tourism, but most of them sell goods and services outside their area. The high season concerns mostly micro-scale businesses whose one third is closed in winter months.

The appearance of prevailing enterprises requiring a large surface area - talking about mainly multinational supermarket chains in the fist place - significantly influenced the success of micro, small and medium-sized businesses, mostly that of enterprises in retail trade within the category and unfortunately not always in a positive way. Micro-scale businesses can be a match for them if they cluster together or provide services that the rivals are not able to offer. There is justification for the existence of trading and catering businesses employing a small number of staff even in towns and villages further from the shore of the lake, although it is a fact that near-shore places come to the front with the boom of tourism. Most of them judged their businesses' profitability and success to be average.

Shop-owners evaluate all their decisions at an opportunity cost and most of them take into consideration the interests sacrificed for the sake of the decision. Decision-making may be influenced by parents' business and also by the endeavour to become independent (Scharle, 2000). According to empirical studies done in the early 1990s, the proportion of 
men and elderly among the self-employed was higher in comparison with that of the employees (Blanchflower-Oswald, 1991).

In the case of small and medium-sized businesses owners are employees at the same time, besides having also production and sales as their tasks. Mainly in the case of microsized enterprises, if owners take their shops' interest into account, it may also occur that they have to risk their families' livelihood. In this case private means and business means do not separate. Small businesses play an important role in employment and it is common that they also create well-trained labour force for big companies.

\section{THE RESULT OF HYPOTHESIS STUDIES}

\section{Correlation can be observed between the motivation of taking up a business and} the year of their launch.

The change of the regime and the initiatives of privatisation in the '90s had an effect on the structural changes of the labour market and its effects could be felt also in the Lake Balaton Resort Area. The possibility of businesses became the symbol of free economy, autonomy and creatable wealth, then as experience shows this illusion seems to have vanished. Entrepreneurs endeavoured to maximise profits, and astutely took advantage of those loopholes that were made possible by law. Those initiative skilled workers steeled with relatively well-based professional experience, marketable knowledge and good contacts that had the chance and courage set up businesses besides or by giving up their main job. A further reason for the sector's growth is the wish to maintain and increase the living standards, as running a business means a possibility of making an income, or at least earning e3xtra money.

The justification and results of our research are also supported by the aspect appearing elsewhere in the technical literature (Botos, 2005), which states that challenges of globalisation has had an impact on small businesses, as well. The global space promoted free trade and the movement of capital. Within an economy each multinational company has overwhelming monopoly over smaller companies. As long as retail trade is taken as a basis, supermarkets moving to town and city centres ruin the viability of micro and small businesses. Unfortunately, these latter ones get into an unfavourable situation as opposed to the big ones being concentrated geographically that might as well extend their opening hours up to 24 hours a day and get advantageous bargaining power through their cheap prices. The motivation of launching enterprises has been examined by several researches in 
Hungary which usually use the labour market model of self-employment. Róna-Tas (1994), Kuczi-Makó (1996) researched the role of the family pattern, good contacts and the importance of natural endowments. Laky (1998), presented the disadvantages of unemployment as the variable of his research. Gábor's study (1994) already shows an essential difference between the group of the self-employed and that of the unemployed. The disintegration of business contacts of former companies as well as the labour market closing gradually both contributed to a number of micro and small enterprises coming into existence.

In our opinion, in the case of family businesses one of the major problems might be caused by ignoring involving outsider experts, while the co-operation of generations might become difficult and the family's financial security is more important than business profits that can be made by taking risks. It has the advantage of providing the business with cheap and reliable staff, which can definitely contribute to supporting self-employment.

One of the causes of the growth in the rate of self-employment is that a certain group of workers has difficulties finding a job, while another cause derives from the extended possibility, the growing demand for products and services. Nowadays the latter statement has become more dominant, as the expansion of business possibilities plays a bigger role than unemployment. When a new business is launched, entrepreneurs consider what would be if they made a living as employees, what the costs of potential unemployment are and whether becoming independent has more advantages than disadvantages. Furthermore, they get and pass on the patterns inherited in his family, as well as observing the market conditions and the actual interest rate. In Table3 the correlation between the year of establishing a business and the motivation is examined by means of a cross-table, the values of the table show a relation between the two examined variables and their correlation, besides showing their direction. As a matter of fact, they show the distribution of the combined frequency. In both cases, it is about nominal variables. The row variables are independent $(\mathrm{X})$, while the column variables are dependent $(\mathrm{Y})$. 
Table 1

Correlation between the motivation and setting up a business as for the sample multitude

\begin{tabular}{|c|c|c|c|c|c|c|}
\hline \multirow[b]{2}{*}{$\begin{array}{l}\text { Year of the } \\
\text { establishment } \\
\text { (X) }\end{array}$} & \multicolumn{6}{|c|}{ The motivation of the enterprises (Y) } \\
\hline & $\begin{array}{l}\text { Family } \\
\text { reasons }\end{array}$ & $\begin{array}{l}\text { Self-reliance, } \\
\text { Independence }\end{array}$ & $\begin{array}{l}\text { Tackling } \\
\text { problems } \\
\text { of } \\
\text { subsistence }\end{array}$ & $\begin{array}{l}\text { "Forced" } \\
\text { entrepreneur }\end{array}$ & $\begin{array}{l}\text { Reaching } \\
\text { a higher } \\
\text { level of } \\
\text { living } \\
\text { standard } \\
\text { Business } \\
\text { reasons, } \\
\text { challenge }\end{array}$ & Total \\
\hline $\begin{array}{l}\text { In or before } \\
1990\end{array}$ & $\begin{array}{c}4 \\
1,3 \%\end{array}$ & $\begin{array}{c}3 \\
1,0 \%\end{array}$ & $\begin{array}{c}8 \\
2,7 \%\end{array}$ & $\begin{array}{c}15 \\
5,0 \%\end{array}$ & - & $\begin{array}{c}30 \\
10,0 \%\end{array}$ \\
\hline $\begin{array}{l}\text { Between } \\
1991-1994\end{array}$ & $\begin{array}{c}3 \\
1,0 \%\end{array}$ & $\begin{array}{c}3 \\
1,0 \%\end{array}$ & $\begin{array}{c}29 \\
9,7 \%\end{array}$ & $\begin{array}{c}82 \\
27,3 \%\end{array}$ & $\begin{array}{c}7 \\
2,3 \%\end{array}$ & $\begin{array}{c}124 \\
41,3 \%\end{array}$ \\
\hline $\begin{array}{l}\text { Between } \\
1995-1999\end{array}$ & $\begin{array}{c}4 \\
1,3 \%\end{array}$ & $\begin{array}{c}7 \\
2,3 \%\end{array}$ & $\begin{array}{c}24 \\
8,0 \%\end{array}$ & $\begin{array}{c}38 \\
12,7 \%\end{array}$ & $\begin{array}{c}16 \\
5,3 \%\end{array}$ & $\begin{array}{c}89 \\
29,7 \%\end{array}$ \\
\hline $\begin{array}{l}\text { Between } \\
2000-2004\end{array}$ & - & $\begin{array}{c}2 \\
0,7 \%\end{array}$ & $\begin{array}{c}11 \\
3,7 \%\end{array}$ & $\begin{array}{c}28 \\
9,3 \%\end{array}$ & $\begin{array}{c}7 \\
2,3 \%\end{array}$ & $\begin{array}{c}48 \\
16,0 \%\end{array}$ \\
\hline $\begin{array}{l}\text { In and } \\
\text { following } \\
2005\end{array}$ & - & - & $\begin{array}{c}2 \\
0,7 \%\end{array}$ & $\begin{array}{c}4 \\
1,3 \%\end{array}$ & $\begin{array}{c}3 \\
1,0 \%\end{array}$ & $\begin{array}{c}9 \\
3,0 \%\end{array}$ \\
\hline Total & $\begin{array}{c}11 \\
3,7 \%\end{array}$ & $\begin{array}{c}15 \\
5,0 \%\end{array}$ & $\begin{array}{c}74 \\
24,7 \%\end{array}$ & $\begin{array}{c}167 \\
55,7 \%\end{array}$ & $\begin{array}{c}33 \\
11,0 \%\end{array}$ & $\begin{array}{c}300 \\
100 \%\end{array}$ \\
\hline
\end{tabular}

Source: Own research

As a consequence of the economical structural changes in Hungary when agricultural co-operative farms and industrial enterprises of great importance became privatised in the Lake Balaton Resort Area, a number of local people became unemployed. As shown in Table1, it turned out from their answers that $27,3 \%$ of those who started their businesses between 1991 and 1994 said that they had become self-employed under compulsion, as they 
saw the way out in launching a tourism-related business. 9,7\% designated tackling problems of living as a reason for setting up a business. During the second period of privatisation the "forced" self-employment as motivation also appears (12,7 \%), but it already shows a decreasing tendency. Those enterprises that see their investment as a challenge developed from small and medium-sized enterprises already employing a bigger staff and did so to generate a higher income, not only to ensure their own and their families' living. From 2000 to 2004 the market became more saturated, entrepreneurial taxes became more unfavourable and also business initiative thus diminished.

At the same time holiday-making habits also changed, tourist required services of higher quality, which could be fulfilled only by businesses able to carry out capital expenditure. In and following 2005 only $3 \%$ of those in the examined period started their business activities. This number is probably higher, but the empirical researches finished in 2006, from which no further conclusions can be drawn.

All in all, a 5\% difference, that is margin of error, was allowed with a sample of 300. (Table2). According to the level of significance experienced in case of the examined businesses, the value of errors does not exceed the allowed limit values, thus the $\mathrm{H}_{0}$ hypothesis can be rejected, according to which there is no connection between the two variables. The motivation of establishing an enterprise is significantly different, depending on the year of the launch.

Table 2

Table of results showing the relation of the motivation and the year of the launch

\begin{tabular}{|l|c|c|}
\hline & Value & Significance \\
\hline Pearson's chi-square test & 36,639 & 0,002 \\
\hline Phi-coefficient & 0,349 & 0,002 \\
\hline V quotient by Cramer & $\mathbf{0 , 1 7 5}$ & $\mathbf{0 , 0 0 2}$ \\
\hline
\end{tabular}

Source: Own research

During the analysis we calculated the association quotient by Cramer by means of the Chi-square test statistics. Here, the hypothesis can be accepted on the basis of the level 
of significance, according to which the motivation of setting up a business depends on the year of its launch.

\section{Calculating the V quotient by Cramer:}

$\mathbf{V}=\sqrt{\frac{36,639}{4 \times 300}}=0,175$

In this case, the value of Pearson's chi-square test shows 36,639. The higher this value, the stronger the correlation of the examined variables can be shown. However, in each case the level of significance is within the allowed limit value and connection can be pointed out, its value is low according to the result of the coefficient of association by Cramer. The results of the motivation and the year of the launch cannot be seen random. The year of the launch as a dependent variable plays a role in establishing a business, but even other variables can contribute to making a decision. Our present examination shows that the peak period of privatisation had an effect also on the enterprises in the Lake Ablation Resort Area and sometimes they made "losers" of privatisation winners in the tourism-related sectors. There were enterprises that started under compulsion as a consequence of tackling problems of making a living, but at the time of the survey -which is even more than 10 years later- they made a living by tourists and meeting their demands. Although, in the second half of the '90s many, mostly small and medium-sized businesses saw possibilities in launching enterprises in the tourist destination, seeing a business challenge and the possibility of reaching higher living standards.

Those enterprises in retail trade whose company has already done business with other companies as suppliers do not feel themselves more successful than independent enterprises.

According to the results, those enterprises in retail trade who are active also as suppliers for other companies do not necessarily feel themselves more successful than the ones who are able to work in a completely independent way in the Lake Balaton Resort Area. This can be explained by -among others- the fact that not all the enterprises are able to be open all the year round after the summer season in an area making profit from tourism. For them, it can be a solution to become suppliers of other companies, which means a dependent relation also according to technical literature, however, it is often the only key to 
being open throughout the year. In towns and villages further from the lake, the reason for the existence of catering facilities remains to be justified, as they represent meeting places for local communities in many cases. Many of them along the shore of the lake stay open during the summer season and of course there are some that do their best also by fulfilling the needs of local people or those wanting to relax in health resorts and meeting the requirements of cultural programmes.

The previous-year investments of businesses have an effect on the turnover of micro-sized enterprises.

With our third hypothesis, we examined the simultaneous movement of the previousyear investments and the turnover by means of regression analysis, which was proved in case of micro-sized businesses employing less than 9 people. They worked as individual businesses and limited companies. Investments on development played a bigger role in the case of these enterprises than in that of medium-sized businesses, where the amount of money allocated for development makes up a smaller part of the turnover. This means that the hypothesis proved to be true with micro-sized enterprises can be explained with the size of investment and the return on investment, which is required for it.

In recent years, $24 \%$ of the capital invested in enterprises (75 businesses) has aimed at complying with EU standards. Carrying the burden of introducing the HACCP system was heavier in the case of corner shops and restaurants. Development aimed at improving quality made up 25\% (with 83 enterprises) of all the investments, besides that a significant ratio was represented by those who began renovating real estate with a view to providing customers with services of higher quality. Enterprises allocated little for marketing, nevertheless, a customer-oriented business activity would serve not only their own improvement, but it would also make the Lake Balaton Resort Area more successful.

\section{CONCLUSIONS}

The situation of enterprises in retail trade and catering in the Lake Balaton Resort Area can be improved through getting acquainted with economic-sociological progresses. Significant participants can support the region's situation by means of new guidelines of development and thinking together. After studying the technical literature related to this topic and doing empirical researches, we came to the following answers to the problems raised by us.

We hold it important to finalise the boundaries of the Lake Balaton Resort Area and put under the economical administration of only one organisation. Lake Balaton does not 
have its "owner", which is a big problem with developments, handing in tenders, as it does not belong to any of the regional categories falling within prevailing laws. At the same time all the three regions sharing Lake Balaton utilising their own sources to develop Lake Balaton, however, they are forced to spend those financial sources on other things, too, to develop their own region, as well.

The support of the region's micro, small and medium-sized enterprises should be realised both at a central and local level (with tax privileges!). It has already been tried to whitewash the economy with state regulations (e.g.: a special temporary entrepreneurial permit), but this definitely does not mean a safe subsistence for employees.

Following the $90 \mathrm{~s}$, private enterprises became activities of higher prestige and supported by the state. If this field enjoyed priority again, we would experience a regional boom in the economy in the long run.

The region's population-retaining power would increase by means of creating jobs, supporting small businesses if these companies could spend their turnover not only on livelihood and paying their employees, but they could develop further with subsidies and tax privileges. The measure would probably create services of better quality, a more aesthetic environment and more jobs. The prospective decrease of public rates and taxes results in improving the situation of the entrepreneurs, which may directly increase the region's population-retaining power and the attraction of the resort area. High priority should be given to small and medium-sized businesses that would become more competitive against the multinational companies by -among others- clustering into supermarket chains and can reduce the negative seasonal effects.

The population-retaining power of the country and the resort area should be based not only on tourism, but new ways should be opened towards other market-leading industries that keep young people in the region. Beyond commerce, it can also represent a way out of the seasonal employment to develop education, research and development or the health and wellness tourism getting increasingly stronger.

Developing the regional marketing towards potential and actual visitors is also a preferential area. The improvement of the image of Lake Balaton is now taking place with traditional means of media (publicity, advertisements). What we think more important is the change of attitude of both local entrepreneurs and the local people of the tourist destination, which is nothing else but the moving together of "emotion and intelligence". In our opinion - if we would like to run a profitable business in tourism-related industries - what has to be understood and done about is that guests come back to the destination if they are treated 
fairly and are more than welcome and their return is expected whole-heartedly, besides appreciating the region's touristic attractions. That may also mean that an entrepreneur should not make a living for the whole year with prices put up in high season by selling goods and services at different prices for locals and foreigners. The customers should get the product of that quality they paid for.

Owing to changed needs and government intervention (holiday vouchers), domestic demand has increased for those B\&Bs, guesthouses and hotels that offer everything on the spot fulfilling the demands of "comfort" tourism. The period of the high season could be extended - also in those places of the resort area where there is no thermal spa, so fewer people visit them in winter seasons - by accommodation providers realising improvements and those places now being built will be complemented with hot-water blocks, sauna and other services, complying with holiday-makers' habits. By pooling forces, for instance cooperating with nearby restaurants, half or full board accommodation can be offered to customers. In this way, entrepreneurs can complement and help each other's job. Realising such improvements makes sense even in places further from the shore of the lake, which results not only in the growing number of visitors, but it also creates jobs and increases real estate prices.

Outlining and realising a good marketing conception could support a faster return on investment even in the case of micro-sized businesses.

It must be noticed, however, that trading and catering businesses can only realise part of the development of the touristic suprastructure as their own objective of development, which is not enough in itself to attract tourists. The lack of the things mentioned above is a discouraging factor, but they are already basic requirements now. To increase the number of the tourists and the length of their stay, a "complex adventure/experience package" should be offered, which supposes other types of cooperation.

\section{LITERATURE}

Babbie E. (2001). A társadalomtudományi kutatás gyakorlata, Balassa Kiadó- Budapest, 212. p.

Blanchflower D. G. - Oswald A. (1991). Self-Employment and Mrs Thatcher's Enterprise Culture, LSE Economic Performance, discussion paper, no. 30

Botos K. (2005). Kisvállalkozások és gazdaságpolitika, Polgári Szemle, 1. évf. 9. szám http://epa.oszk.hu/00800/00890/00008/article58.html, 2008. 02. 20 
Buday-Sántha A. (2007). A Balaton-régió fejlesztése, Saldo Kiadó, Budapest 65-98.p.

Czakó Á. (1997). Kisvállalkozások a kilencvenes évek elején (Vállalkozás és polgárosodás) Vállalkozások-e a kisvállalkozások?, Szociológiai szemle 1997/3. sz. 93. p.

Csalagovits I. (2005a). Észrevételek a Balaton régió és a dunántúli statisztikai régiók területfejlesztési koncepcióihoz 1.; Comitatus: önkormányzati szemle, 15. évf. 1-2. sz. 103109. p.

Csalagovits I. (2005b). Kiegészítés és javitások a január-februári Comitatus-ban megjelent, "Észrevételek a Balaton régió és a dunántúli statisztikai régiók területfejlesztési koncepcióihoz" Comitatus: önkormányzati szemle, 15. évf. 3. sz. 77-80 p.

Darabos F. (2001). Falu város régió, 2001. 4. sz. 18-20. p.

Gábor R. I. (1994). Kisvállalkozás Magyarországon - virul vagy satnyul? Közgazdasági Szemle XLI. évf. 7-8. sz. 709-719. p.

Horváth Gy. (1996). A magyar regionális politika és az európai kihívások. In: Vezetéstudomány, 1996/1. sz. 17-29. p.

Jancsik A. (2001). Turisztikai marketing. Jegyzet, Pannon Egyetem Turizmus Tanszékének kiadványa

KSH (2001). Velencei-Tó-Vértes Üdülőkörzet, KSH Fejér és Komárom-Esztergom Megyei Igazgatósága, Székesfehérvár-Tetebánya, 38-56. p.

KSH (2006). A Balaton Üdülőkörzet idegenforgalma, Központi statisztikai Hivatal Veszprémi Igazgatóság kiadványa, 7-9; 50 p.

KSH (2007). A német turisták szerepe Magyarország idegenforgalmában, Statisztikai Tükör, 42. évf. 1. szám, Tájékoztatási főosztály és a Tájékoztatási, koordinációs és elemző osztály jelentése alapján, 2. p.

KSH (2008). A Tisza-Tó Kiemelt Üdülőkörzet jellemzői, Debrecen, 5-36.p.

Kovács E. (2001): Modernizációs folyamatok egyes dunántúli településeken, Doktori (PhD) értekezés, 96-97. p.

Kuczi T.- Makó CS. (1996): Links between the Resources of Entrepreneurs and the Growth of Businesses, Kutatási jelentés

Laky T. (1998). A kisvállalkozások növekedésének korlátai. Szociológiai szemle, VIII. évf. 1. sz. $23-40$ p.

Laposa J. (2007). Balaton-törvény: támadás minden irányból: nincs megállás, tovább nö a beépítésre szánt terület, Falu város régió, 2007/2. sz. 31-33. p.

Lengyel I.- Rechnitzer J. (2004). Regionális gazdaságtan, Dialóg Campus Kiadó, 19-35. p.

Mester, T. - Polgár, J. - Kiss, K. (2006): A Balaton turizmusának alakulása a statisztikák tükrében, Turizmus Bulletin 10. évf. különszám, 63. p.

Mészáros R. (2000). A társadalomföldrajz gondolatvilága, SZTE Gazdaság-és Társadalomföldrajzi Tanszéke, Szeged, Jegyzet

Molnár T. (2001). Társadalmi-gazdasági struktúrák regionális jellemzői a NyugatDunántúlon, Keszthely. PhD. Doktori értekezés 
Nemes Nagy J. (2005). A Balaton régió gazdasági fejlettsége a GDP térségi becslése tükrében, (Kutatási jelentés). R-DATA Bt., ELTE Regionális Földrajzi Tanszék, MTAELTE Regionális Tudományi Kutatócsoport, Budapest

Oláh M. (2003). Egy rendhagyó régió rendhagyó helyi társadalmáról; Comitatus: önkormányzati szemle, 13. évf. 7-8 sz. 27-42. p.

Pálné Kovács I. (1999). Regionális politika és közigazgatás, Dialóg Campus, Budapest-Pécs

Probáld F. (1995). A regionális földrajz helye a geográfiában. Háttérvázlat. In: Regionális Tudományi Tanulmányok, 2. sz. 35-63. p.

Róna - Tas Á. (1994). The first shall be last? Entrepreneurship and communist cadres in the transition from socialism, American Journal of Sociology,Vol. 100, No. 1, 40-69. p.

Scharle Á. (2000). Önfoglalkoztatás, munkanélküliség és családi kisvállalkozások Magyarországon, Közgazdasági szemle, XLVII. évf. 3. sz. 250-274. p.

Turisztikai adattár (2008). A Dunakanyar turizmusának összehasonlítása néhány kiemelt üdülökörzettel, http://www.dunakanyar.hu/index.php?page=regio\&sub=doc; 2008. 09. 01.

Vizvári B. - Bacsi Zs. (2003): Structural problems in the Hungarian agriculture after the political turnover, Journal of Central European Agriculture, Vol. 4 No. 2, 175-184. p.

2000. évi CXII. Törvény, a Balaton Kiemelt Üdülőkörzet Területrendezési Szabályzat

\section{Other references on the internet, relevant laws and regulations:}

- EUVONAL (2008):http://www.euvonal.hu/index.php?op=kozossegi_politikak\&id=15 2008.05.07

- 35/1998. (III. 20) Országgyülési határozat

- 2000. évi CXII. Törvény, a Balaton Kiemelt Üdülőkörzet Területrendezési Szabályzat

- 77/2005. (XII.25.) Országgyülési határozat 